\title{
Aviation Investigation: International and National Legal Standarts
}

\author{
Olena Makeieva *[0000-0001-6101-2951], Ludmila Shapenko [0000-0001-7351-641X] \\ National Aviation University, Kyiv, Ukraine \\ *maklena72@ukr.net
}

\begin{abstract}
The authors explored the characteristics of current trends in the domestic legal support development for the aviation accidents investigation by conducting a comparative analysis of national and international legislation on the investigation of aviation accidents and incidents. The methodological basis of the study have been represented by general and special legal methods, including dialectical, comparative law and statistics, which studied the problems of implementation of international law in the national law of Ukraine, analyzed analytical indicators of the number of aviation events and incidents in recent years, and objective preconditions for reforming the domestic legal framework under the influence of international standards and recommended practices of the International Civil Aviation Organization have been identified. Based on the analysis of regulations, the legal status and scope of competence of the National Bureau for Investigation of Aviation Events have been determined, as well as the prospects for further research in this area and ways to improve the legal regulation of aviation accident investigation have been outlined. The materials of the article can be used by researchers, scientific-pedagogical staff, flight safety management and aviation safety specialists in terms of studying, implementing and improving the rules of investigation of aviation incidents and incidents.
\end{abstract}

Keywords: aviation investigation, aviation safety and security, aviation accidents and incidents, international aviation organisations, international and national legal standarts.

\section{INTRODUCTION}

In the current conditions of dynamic development of public relations in Ukraine, the role of air transportation is significantly increasing, as the functioning of the world air transportation market creates preconditions for strengthening integration processes by ensuring free movement of passengers and cargo, involving countries in international cooperation which is an important factor of national economic growth. In this regard, it is important to ensure proper legal regulation of the aviation industry, which should consist not only of national legislation but also of a number of international (intergovernmental) agreements, the rules of which regulate procedural issues related to air transportation and ensuring aviation safety. Another important point, in addition to the availability of appropriate legal regulation of the aviation industry, is the availability of appropriate aviation infrastructure.

The increase in the role of air transportation is evidenced by statistical data, during January - September 2019, passenger and cargo transportation was carried out by 29 domestic airlines, which performed a total of 79.7 thousand commercial flights (against 77.1 thousand for the same period last year) [1]. If we analyze the statistics for 2020, there is, unfortunately, a significant decrease in air traffic (both domestic and foreign), due to the COVID-19 pandemic and its rapid spread around the world. Thus, only in January-March 2020, the volume of passenger traffic by Ukrainian airlines decreased compared to the same period last year by $17.3 \%$ and amounted to 1953.8 thousand people, including international - by $17.1 \%$ and amounted to 1757 thousand people [2].

One of the priorities of aviation in the XXI century is to ensure flight safety. An important way to increase the level of flight safety is to investigate aviation accidents by establishing their causes and taking measures to prevent the recurrence of similar events in the future. In the current conditions of the rapid development of the aviation industry, it is important to study the legal framework for the investigation of aviation incidents and incidents, the study of national and international standards for the mechanism of investigation of aviation 
incidents. The study of this issue will help to focus the attention of aviation personnel to the established norms and recommendations, which will help to avoid the aviation accidents and incidents circumstances. As you know, the legislation of Ukraine in the field of civil aviation is in the process of reform, and needs to improve legal regulation at the present stage of development of the legal system of Ukraine.

The purpose of the article is to make a comparative analysis of the state of national and international legislation on aviation accident investigation, to investigate the level of implementation of the Chicago Convention of 1944 in Ukrainian legislation on aviation accident investigation in order to ensure aviation safety, improve legal regulation of aviation accident investigation; identify prospects for further research in this area and ways to solve the problems.

\section{MATERIALS AND METHODS}

Problems of research of aviation events in the works covered O M Alekseev, N M Akhtyrska, A S Bichkov, V P Verchenko, Yu A Zadorozhny, Yu K Ziatdinov, Yu V Korneev, O I Motlyakh, A V Filippov and others, but they did not analyze the legal regulation of aviation accident investigations.

General scientific methods and approaches were used in the process of scientific research. To study the problem of implementation of international law in national law, a comparative legal method was used, to determine the level of the number of aviation events and incidents, a statistical method was used.

\section{RESULTS}

The issue of legal security of civil aviation is a priority for the development of air law of Ukraine, the sources of which are international and national legal regulations. The main areas of legal regulation of civil aviation are regulated by international treaties and conventions. Thus, any aviation safety system is based on feedback taken from aviation accidents and incidents, which requires the strict application of confidentiality rules to ensure the valuable information sources availability in the future. Therefore, related data, especially sensitive safety information, should be protected in an appropriate manner. Personbal information must be totally protected and should not be used against that person, in full respect of national and international law [3].

One of the tasks for the development of the aviation industry, which are specified in the National Transport Strategy of Ukraine until 2030, is the organization and use of Ukrainian airspace in accordance with ICAO standards and recommended practices, the European Air Navigation Safety Organization (Eurocontrol), other international aviation organizations and legislation EU [4]. Ukraine currently has obligations under 39 international treaties under international air law (including 29 under the auspices of the International Civil Aviation Organization (ICAO), 1 under the auspices of the European Civil Aviation Conference (ECCA), 2 under the auspices of the Joint Aviation Authorities (JAA) and 7 under the auspices of the European Organization for the Safety of Air Navigation (EUROCONTROL) [5, p.66].

In addition, Ukraine is a member of many international organizations that regulate relations in the field of aviation. Such organizations include the International Civil Aviation Organization (ICAO), which aims to develop principles and methods for international air navigation and to promote air transport planning and development to ensure the safe development of international civil aviation around the world. Ukraine has been a member of this organization since September 9, 1992. Ukraine has also been a member of the European Organization for the Safety of Air Navigation - EUROCONTROL (European Organization for the Safety of Air Navigation) since May 1, 2004. Among the organizations in which Ukraine is a member are: Joint Aviation Authorities (JAA), Interstate Aviation Committee, European Organization for Civil Aviation Equipment - EUROCAE (European Organization for Civil Aviation Equipment) and others.

The problem of ensuring the safety of civil aviation is divided into two aspects. First, it is the application of appropriate measures and the establishment of rules to ensure the technical and reliable operation of aircraft as a kind of "safety" [6]. Secondly, these are specific legal issues of combating acts of illegal human interference in the activities of civil aviation that threaten its safety. To ensure security, each State, in cooperation with ICAO, must develop, approve, and implement procedures, mechanisms, and joint actions in accordance with international law and modernize its national legislation. In the European Union, the aviation security system is based on close cooperation between the European Commission, the European Aviation Safety Agency, Eurocontrol, the national civil aviation authorities, and the security investigation authorities of the Member States, as well as aircraft manufacturers, airlines and other participating companies. The basis of this system consists of a set of safety rules that apply to both industry and civil aviation authorities.

ICAO is one of the most representative intergovernmental organizations with the status of specialized UN agencies, whose functions and competencies are special. To perform its functions, ICAO has the right to make decisions or participate in international air navigation and international air transport. In particular, the organization develops International Standards for the Investigation of Aviation Accidents and Incidents on the basis of and in accordance with the Convention on International Civil Aviation, adopted in Chicago on December 7, 1944. One of the 
important tasks of ICAO referred to in Article 44 of the Chicago Convention of 1944, is: to create the safe and orderly development of international civil aviation worldwide through competition; promoting flight safety. With regard to the implementation of domestic law, these standards, contained in the annexes to the Chicago Convention, must be implemented in national laws and regulations, fully transposing the content of the standards. As noted above, ICAO standards are contained in 18 annexes to the Chicago Convention and are supplemented by the Air Navigation Services Regulations (PANs) and many guidelines that provide practical guidance on the implementation and application of the annexes.

Investigation of aviation accidents is especially important for aviation safety not only to find out the cause of aviation accidents but also to prevent previous mistakes in aviation. To determine the level of implementation of international law into national law, consider Annex 13 to the Chicago Convention on the Investigation of Aviation Cases. This application is dedicated to case prevention. Particular attention is paid to the rapid identification and explanation of roles and responsibilities. Thus, according to the annex in the state where the accident took place, it shall take all necessary measures to preserve the material evidence and ensure the reliable protection of the aircraft and everything that is there for the time necessary for the investigation. It shall also send a notification of an aviation accident or serious incident with minimal delay by the most convenient and expeditious communication to the State of Registry, the State of Operator, the State of Manufacture, and the IOC if the maximum mass of the aircraft exceeds $2250 \mathrm{~kg}$ or is a turbojet. The next step is for the scene to initiate an investigation into the circumstances of the accident and be responsible for conducting such an investigation, but may delegate all or part of that investigation to another state or regional accident investigation organization by mutual agreement and consent. A full-fledged aviation investigation body shall be established, which shall be granted independence in conducting the investigation and unlimited powers to conduct it in accordance with the provisions of this Annex [7].

According to this annex, an investigation shall include: the collection, registration and analysis of all relevant [8] information on the aviation incident or incident; if necessary, development of safety recommendations; if possible, establishing the causes or factors; final decision (States shall not disseminate, publish or permit the use of the draft report or any other documents obtained in the course of an aviation accident investigation, except where such reports or documents have already been published or made public to those latter States). The aviation enterprises such as airlines, airplane manufacturers, airports, air traffic services, and safety regulatory authorities have been working together to make our flies safer. Among these aviation stakeholders, mentioned above, there are another ones, for example air accident investigators, that determine the causes and results of aviation accidents and incidents to prevent similar events in the future [9].

The state establishes a system of mandatory reporting of incidents in order to facilitate the collection of information on actual or potential shortcomings in ensuring safe flights. But the State of registration is the only one obliged to investigate in the event that the incident takes place outside the territory of any State (according to Annex 13). Accordingly, by systematizing all information, ICAO publishes a guide to aviation accident prevention, which also forms a "systems approach" that is the basis for accident prevention, namely: reporting information on cases supported by a no-fault policy, airport security review, manufacturers and airlines, and the development of day-to-day management systems that can be implemented in all aviation organizations)

Along with the operational-technological component of the aviation accidents investigation process, it is also important to avoid and overcome aviation legal risks, id est hazards, the probability of which is associated with the absence, inconsistency or unclear regulation of operations in relevant regulations or changes in legal acts. Fully agreeing with the scientific work of Bezzubov D, Bakhov I, Klyuyeva Y and Byrkovych T, it should be noted that a clear concept of aviation legal risk managemen has to be an integral part of civil aviation security control in Ukraine [10].

What are the rules of national law contain the legal basis for the investigation of aviation accidents, Are the rules of international law implemented in the national? National legislative acts of Ukraine include the Air, Customs, Criminal Codes of Ukraine, the Code of Ukraine on Administrative Offenses; Laws of Ukraine, Law of Ukraine "On the State Program of Civil Aviation Security", Aviation Rules of Ukraine "Rules of Air Transportation and Passenger and Baggage Service", "On the National Police", "On the Security Service of Ukraine", "On the State Border Guard Service of Ukraine", "On border control", "On operational and investigative activities" and others.

According to the Air Code of Ukraine, aviation entities directly take measures to ensure the safety of aviation and are responsible for it [11]. In accordance with Article 9, the investigation of aviation incidents, incidents and emergencies with civil aircraft and aircraft of Ukraine and foreign civil aircraft that occurred on the territory of Ukraine, as well as violations of the requirements for the use of airspace of Ukraine is carried out by a specialized expert institution. Which is formed and the status of which is determined by the Cabinet of Ministers of Ukraine. In addition, this expert institution 
may not be subordinated to or otherwise dependent on the authorized body for civil aviation.

Certain provisions on the investigation of aviation incidents are defined in the Air Code of Ukraine in Section XVII "Investigation of aviation incidents". Thus, in accordance with Article 119, the procedure for organizing the investigation of aviation incidents and incidents is defined: all aviation incidents, serious incidents, incidents, emergencies, and damage to aircraft on the territory of Ukraine, as well as violations of the use of Ukrainian airspace are subject to investigation to establish their causes and take measures to prevent such future events, which is a technical investigation. Technical investigations of aviation incidents, serious incidents, incidents, emergencies, and damage to aircraft on the ground are conducted in accordance with the rules and in the manner approved by the Cabinet of Ministers of Ukraine. In addition, the Code states that any administrative, official, prosecutorial, judicial investigation aimed at establishing guilt or liability must be conducted separately from the technical investigation of aviation accidents, serious incidents, incidents, emergencies, and damage to aircraft on the ground.

In accordance with the Regulations on National Bureau for the Investigation of Aviation Accidents and Incidents of Civil Aircraft (hereinafter referred to as the National Bureau), it was established to: 1) carry out technical investigations of aviation accidents, serious incidents, incidents, emergencies, damage to civil aircraft and aircraft on the ground, violations of airspace use, in particular during air traffic services and organization (hereinafter - aviation events) that occurred on the territory of Ukraine with civil aircraft; 2) ensuring participation in the technical investigation on the territory of foreign states in which aviation accidents occurred with civil aircraft of Ukraine; 3) preparation of conclusions and recommendations based on the results of collection, analysis, research and generalization of data related to flight safety, in order to prevent aviation events that occurred on the territory of Ukraine [12].

The opinion of the team of authors is interesting. V P Serdyuk, E V Serdyuk and O O Fast, who according to the results of the research proposal to change the name "National Bureau for Investigation of Aviation Accidents" to "National Bureau for Technical Investigation of Aviation Accidents" with the already defined status of a specialized Expert Institution, which will more clearly define compliance of the name with the content and will eliminate different interpretations in theory and practice regarding the procedural status of this body [13].

The next step in the investigation of aviation accidents was the adoption in 2013 of the Guidelines for the Investigation of Aviation Accidents and Accidents, developed by the National Bureau in accordance with ICAO standards [14]. This document emphasizes the importance of an objective investigation of aviation accidents. As noted in paragraph 1.2, an aviation event indicates the presence of hazards or deficiencies in the aviation system. Therefore, a competent investigation should identify all the underlying and immediate systemic causes of the event and recommend appropriate safety measures to avoid hazards or eliminate deficiencies. The investigation may also identify other hazards or deficiencies in the aviation system that was not directly related to the causes of the incident. Therefore, a properly conducted investigation of aviation accidents is one of the important means of preventing aviation accidents.

One of the principles of aviation accident investigation is efficiency. According to the purpose of the investigation of aviation incidents and incidents, A V Filippov believes, has a number of features that distinguish it from a criminal investigation. First of all, it is the efficiency due to the goal: a constructive result (objective identification of the causes and development of appropriate recommendations to prevent the recurrence of similar events) should be achieved as soon as possible [15, p. 159]. In May 2020, a resolution of the Cabinet of Ministers of Ukraine approved the Regulations on the National Bureau for the Investigation of Aviation Accidents and Incidents of Civil Aircraft. The regulation defines the purpose and subject of activity, legal status, property and management, financing, etc [16].

This document defines the subject of the bureau's activities, including ensuring the objective investigation of aviation events that took place on the territory of Ukraine, civil aviation and aviation events that took place on the territory of foreign states by civil aviation of Ukraine; reading, reproduction, and analysis of records of on-board recorders and ground means of objective control, if necessary - determination of the technical center, including abroad. It is important in the activities of the National Bureau to ensure the collection of information on identified operational and flight factors and risks, deviations, as well as analysis, research, and synthesis of data related to flight safety As already mentioned, it is important for the National Bureau to prepare reports and recommendations on the results of aviation accident investigations and provide the authorized civil aviation authority, other interested executive bodies, and aviation enterprises, institutions, organizations with reports and recommendations on aviation accident investigation and prevention recommendations. In order to promptly investigate aviation accidents, this institution cooperates with executive authorities, local governments, enterprises, institutions, organizations, and the public during the organization and investigation of aviation incidents, site security, and preservation of material evidence, and cooperates with the Ministry of Foreign Affairs, consular institutions of Ukraine, competent international 
organizations and aviation authorities of a foreign state, on the territory of which the aviation incident took place, with a civil aircraft of Ukraine or if such aircraft (equipment) was manufactured in Ukraine; relevant organizations of the state of national registration of a civil aircraft or its operator, if the plane crash occurred on the territory of Ukraine. In order to find out the causes of aviation accidents, the bureau keeps records of aviation events. For example, the website of the National Bureau of Aviation Events for the first half of 2020 provides a table According to the data received by the National Bureau of Investigation of Aviation Events, in the first half of 2020, in the operation of civil aircraft of Ukraine for passenger and cargo transportation, during aviation works, training flights and during the operation of general aviation aircraft, entered in the State Register of Civil Aircraft occurred: 3 accidents (1 - during transport and 2 - during general aviation flights); 9 incidents; 5 violations of the procedure for the use of airspace. For 6 months of the current year in Ukraine there were 7 events with foreign civil aircraft [17].

\section{DISCUSSIONS}

Issues of cooperation between government agencies to ensure security and investigate incidents are also regulated in different ways. Thus, in order to effectively perform its own functions, the NBRCA is obliged to cooperate with other state bodies, in particular with the State Aviation Service of Ukraine. The legal basis for such cooperation at present is the Memorandum of Cooperation of the National Bureau for Investigation of Aviation Incidents and Incidents with civil aircraft and the State Aviation Service of Ukraine [18].

This document defines the relationship between the parties to the interaction on the system of accounting for aviation incidents and incidents, the system of mandatory notification of incidents and information exchange, the formation of commissions to investigate incidents, mutual access to information. It should be noted that in accordance with paragraph 14.5 , the provisions of this Memorandum are reviewed every 12 months from the date of entry into force, and if necessary, it is amended in advance by the Parties to the interaction. The Memorandum was adopted on October 10, 2016, and no information on its revision, addition or clarification has been made public (despite the urgent need due, in particular, to the adoption of the Cyber Security Strategy and other regulations.

Issues of the interaction of the State Aviation Service of Ukraine with law enforcement agencies are regulated by the resolution of the Cabinet of Ministers of Ukraine [19], according to which the State Aviation Service informs law enforcement agencies about identified violations in civil aviation or information received about them; provides advisory assistance in identifying and identifying offenses related to the use of Ukrainian airspace, conducting activities in aerodrome areas that affect aviation safety, as well as the development, manufacture, repair and operation of aircraft, conducting business in the field of civil aviation, air navigation services, aviation security. The task of great importance task of all investigation authorities is to properly evaluate safety. Different activities play an important role, including priority activities related to saving people's lives and property, protecting outer subjects against the results of aviation accident effects [20].

Law enforcement bodies, within the framework of cooperation within their powers, inform the State Aviation Service about the revealed facts of offenses in the field of civil aviation or the information received about them; at the request of state inspectors or persons authorized to conduct inspections, the State Aviation Services shall provide assistance in the performance of their official duties. Joint inspections with law enforcement agencies are conducted in case of revealing facts or obtaining information on the commission of offenses in the field of civil aviation, which was received by the State Aviation Service and / or law enforcement agencies. Authorized persons of the State Border Guard Service take part in conducting inspections within the controlled border areas, and if necessary - within the territories of regions of Ukraine adjacent to the state border or to the sea coast, which is protected by the State Border Guard Service.

\section{CONCLUSIONS}

1. The analysis of the listed legislative acts shows that special laws and bylaws take into account the recommendations of the ICAO international organization on air accident investigation in the interaction of interested state bodies, but do not regulate in detail the procedural issues of interaction of investigative bodies and experts of the National Bureau of Aviation Investigation. ICAO's idea of investigating and establishing by experts of the technical investigation body only the technical side of the cause of the accident.

2. A study of the international legal experience of cooperation between law enforcement agencies and technical investigation bodies of an air accident shows that the ICAO recommendations for investigation by the authorized bodies of the states in which the air accidents occur are implemented, and the states parties to the Convention adhere to the principles of non-interference. there was an aviation event, and the need to study only its technical side.

3. The analysis of legal norms gives grounds for conclusions on the need to amend the current legislation in order to harmonize it and ensure proper and effective implementation of the responsibilities of the National Bureau. First, the National Bureau for the Investigation of Aviation Accidents and Incidents with Civil Aircraft is an extremely important body for ensuring flight safety, identifying threat factors, and preventing the risk of 
incidents in civil aviation, while its powers are defined by a provision that regulates the purpose to a very limited extent of functions, powers.

4. It is obvious that it is expedient to adopt a special Law of Ukraine "On the National Bureau for Investigation of Aviation Incidents and Incidents with Civil Aircraft", which carefully, in accordance with international standards, describes the structure, functions, powers, procedures, and terms of interaction with relevant authorities, government agencies, international cooperation, etc.

\section{REFERENCES}

[1] Statistics in the field of air transport, Ministry of Infrastructure of Ukraine, available at: https://mtu.gov.ua/content/statistichni-dani-vgaluzi-aviatransportu.html

[2] Operational information on the main indicators of the aviation industry for January-February 2020, State Aviation Service of Ukraine, available at: https://avia.gov.ua/pro-nas/statistika/operativnainformatsiya/

[3] Balcerzak, T. A. (2017), "Just culture"? Conflicts of interest in the investigation of aviation accidents, Scientific Journal of Silesian University of Technology. Series Transport, vol. 94, pp. 5-17

[4] On approval of the National Transport Strategy of Ukraine for the period up to 2030, May 2018, 30 430-r., Order of the Cabinet of Ministers of Ukraine, available https://zakon.rada.gov.ua/laws/show/430-2018-r

[5] Syryichyk, T. Furhalski, A. Klimkevych, Ch. Kamola, M. Diachenko, T. Puhachov, M. and Filipenko, O. (2010), Transport policy of Ukraine and its approximation to the norms of the European Union, Kyiv, Analytical and advisory center of the Blue Ribbon.

[6] Ilyasu Anda, Isah Omeiza Rabiu and Enesi Femi Aminu (2017), "A Safety Data Model for data analysis and decision making", International Journal of Information Engineering and Electronic Business, vol. 9, no. 4, pp. 21-30, DOI: $10.5815 / \mathrm{iji}$ ieeb.2017.04.04

[7] Annex 13 to the Convention on International Civil Aviation of December 7, 1944, Investigation of aviation incidents and incidents, available at: https://zakon.rada.gov.ua/laws/show/995_655\#Text

[8] Erick, R. Samwi Kisangiri, Michael and Sabine, Moebs (2019), "Research Based Solution for Linking Higher Learning Institutions Students to Relevant Companies for Field Attachment", International Journal of Information Technology and Computer Science, vol. 11, no. 10, pp. 40-49, DOI: $10.5815 /$ ijitcs.2019.10.06

[9] Balcerzak, T. (2017), "An examination of aviation accidents in the context of a conflict of interests between law enforcement, insurers, commissions for aircraft accident investigations and other entities", Scientific Journal of Silesian University of Technology, Series Transport, vol. 95, pp. 5-17.

[10] Bezzubov, D. Bakhov, I.S. Klyuyeva, Y. and Byrkovych, T. (2020), "Aviation legal risk management: The concept, structure, and categories", Journal of Advanced Research in Dynamical and Control Systems, vol. 12 (4), pp. 703-711.

[11] Air Code of Ukraine of May 19 2011, no 3393-VI (2011), Bulletin of the Verkhovna Rada of Ukraine, vol. 48-49, pp. 536.

[12] Regulations on the National Bureau for the Investigation of Aviation Accidents and Incidents with Civil Aircraft March 2012, Resolution of the Cabinet of Ministers of Ukraine, available at: http://zakon3.rada.gov.ua/laws/show/228-2012-p

[13] Serdiuk, V.P. Serdiuk, Ye.V. and Fast, O.O. (2018), "Current issues of legislative regulation of the investigation of aviation accidents in Ukraine", Current issues of state and law, Helvetyka, pp. 137146.

[14] Aviation Accident Investigation Guide (2013), available at: http://www.nbaai.gov.ua/uploads/pdf/ Investigation_Manual_rev\%208.pdf

[15] Filippov, A.V. (2019), "Investigation of aviation incidents and incidents: harmonization of Ukrainian legislation with international law and European Union law", Legal scientific electronic journal, vol. 1, pp. 193-196.

[16] Some issues of the National Bureau for Investigation of Aviation Incidents and Incidents with Civil Aircraft (May 2020), Resolution of the Cabinet of Ministers of Ukraine, available at: https://zakon.rada.gov.ua/laws/show/417-2020p\#Text

[17] Analysis of the state of flight safety based on the results of the investigation of aviation incidents and incidents with civil aircraft of Ukraine and vessels of foreign registration that occurred in the first half of 2020, available at: http://www.nbaai.gov.ua /uploads/pdf/1st_half_2020.pdf

[18] Memorandum of the National Bureau for Investigation of Aviation Incidents and Incidents with Civil Aircraft and the State Aviation Service of Ukraine, available at: http://www.nbaai.gov.ua/ 
uploads/pdf/Memorandum2016.pdf

[19] Procedure for interaction of the State Aviation Service with law enforcement agencies on issues of civil aviation security (2019), Resolution of the Cabinet of Ministers of Ukraine, Government courier, July 4, no 124.

[20] Konieczka, R. (2017), "How to secure basic evidence after an aviation accident", Scientific Journal of Silesian University of Technology, Series Transport, vol. 94, pp. 65-74. 